\title{
Faktor Risiko Keturunan Diabetes dengan Variabel Perancunya Meningkatkan Prevalensi Diabetes Tipe 2 (Studi Estimasi)
}

\author{
Obesity as the Dominant Risk Factor Influence on the Incidence of Type 2 Diabetes Mellitus \\ (Case Control Study)
}

\author{
Riyanto Riyanto ${ }^{1, \bowtie}$ \\ ${ }^{1}$ Politeknik Kesehatan Tanjung Karang, Indonesia \\ ${ }^{凶}$ Corresponding author: riyanto@poltekkes-tjk.ac.id
}

\begin{abstract}
Kata kunci:
Keturunan faktor

dominan Diabetes,

Obesitas pada

Diabetes.
\end{abstract}

Keyword:

Hereditary dominant factor Diabetes, Obesity in Diabetes,

\begin{abstract}
Abstrak
Latar belakang: Diabetes tipe 2 merupakan gangguan yang dipengaruhi oleh multifaktor, melibatkan baik faktor genetik maupun faktor lingkungan. Tujuan: Penelitian ini bertujuan menemukan besar estimasi faktor risiko keturunan terhadap kejadian tipe 2 dengan mengkontrol mengontrol variabel perancu lain. Metode: Penelitian ini menggunakan desain cross sectional analisis model estimasi dengan variabel utama faktor keturunan. Sampel penelitian minimal 249 responden. Pengukuran dan pengamatan variabel penelitian menggunakan metode wawancara dan pengamatan. Analisis multivariat model estimasi menggunakan uji multiple regresi logistic dan dihitung attributable fraction persen (AF\%). Hasil: Hasil analisis pemodelan multivariat akhir menunjukkan faktor keturunan berhubungan dengan kejadian Diabetes tipe 2 ( $\mathrm{p}$ value 0,000), setelah dikontrol oleh faktor perancu (confounding) IMT, pekerjaan, umur dan obesitas sentral dengan ORadjusted 19,8; 95\% CI: 1,911-9,459). Perhitungan ukuran dampak potensial (AF\%) hasil analisis memperoleh sebesar 48,15\%. Simpulan: Besar estimasi responden yang mempunyai faktor keturunan berisiko 19.8 kali dapat mengalami Diabetes dibandingkan yang tidak mempunyai faktor keturunan setelah dikontrol perancu IMT, pekerjaan dan umur dan obesitas sentral. Hendaknya pengandang Diabetes tipe 2 yang mempunyai riwayat keturunan Diabetes, menjalani gaya hidup yang sehat, sehingga sekitar 48,15\% kejadian Diabetes dapat dicegah melalui faktor keturunan.
\end{abstract}

\begin{abstract}
Background: Type 2 diabetes is a disorder that is influenced by multifactors, involving both genetic and environmental factors. Purpose: This study aims to find a large estimate of hereditary risk factors for type 2 events by controlling controlling for other confounding variables. Methods: This study used a cross sectional design analysis model estimation with the main variable heredity. The research sample of at least 249 respondents. Measurement and observation of research variables using interview and observation methods. Multivariate analysis of estimation models uses multiple logistic regression tests and calculated attributable fraction percent $(A F \%)$. Results: The results of the final multivariate modeling analysis showed heredity was associated with the incidence of type 2 Diabetes ( $p$ value 0,000), after being controlled by confounding factors for BMI, occupation, age and central obesity with ORadjusted 19.8; 95\% CI: 1,911-9,459). Calculation of the potential impact size (AF\%) results of the analysis obtained 48.15\%. Conclusion: The estimated magnitude of respondents who have inherited risk factors is 19.8 times more likely to have diabetes than those without heredity after being controlled by confounders of BMI, occupation and age and central obesity. People with Type 2 Diabetes who have a history of diabetes, live a healthy lifestyle, so that around $48.15 \%$ of diabetes can be prevented through hereditary factors.
\end{abstract}

Copyright (ㄷ 2017 Jurnal Kesehatan Metro Sai Wawai. All rights reserved. 


\section{Pendahuluan}

Diabetes merupakan masalah kesehatan global dan telah menjadi status pandemik (Fain, 2014). sebagai silent killer karena sering tidak disadari oleh penyandangnya dan saat diketahui sudah terjadi komplikasi (Kemenkes RI, 2014). Di seluruh dunia Diabetes mempengaruhi sedikitnya 171 juta orang dan menyebabkan 3,2 juta kematian, setara dengan kematian HIV / AIDS, 6 kematian per menit dan 8700 kematian setiap hari (Biswah, 2006). Diabetes juga menjadi penyebab kematian di Indonesia. Hasil Riset kesehatan Dasar (Riskesdas) tahun 2007, diperoleh penyebab kematian akibat Diabetes pada kelompok usia 45-54 tahun di daerah perkotaan menduduki ranking ke-2 yaitu 14,7\% dan daerah pedesaan, Diabetes menduduki ranking ke-6 yaitu 5,8\% (Badan Litbangkes Depkes RI, 2008).

Sesuai dengan hasil studi global yang menyimpulkan bahwa penyakit Diabetes adalah masalah kesehatan yang besar, terbukti terjadi peningkatan jumlah penderita Diabetes dari tahun ke tahun. Pada tahun 2015 menyebutkan sekitar 415 juta orang dewasa memiliki Diabetes, kenaikan 4 kali lipat dari 108 juta di tahun 1980an. Apabila tidak ada tindakan pencegahan maka jumlah ini akan terus meningkat tanpa ada penurunan. Diperkirakan pada tahun 2040 meningkat menjadi 642 juta penderita (IDF, 2015).

WHO memprediksi kenaikan jumlah pendeita Diabetes di Indonesia dari 8,4 juta tahun 2000, menjadi sekitar 21,3 juta pada tahun 2030, sehingga menunjukkan peningkatan 2-3 kali pada tahun 2035. Sedangkan, International Diabetes Federation (IDF) 2014, memperkirakan terdapat 9,1 juta orang penduduk didiagnosis Diabetes. Indonesia menempati peringkat ke-5 di dunia atau naik dua peringkat dibandingkan IDF tahun 2013 yang menempati peringkat ke-7 di dunia dengan 7,6 juta orang penderita Diabetes (Perkeni, 2015).

Prevalensi Diabetes secara nasional dari hasil Riskesdas tahun 2007 ditemukan 5,7\% (2007) dan tahun 2013 sedikit turun menjadi 5,6\% (2013). Menurut IDF pada tahun 2006 dibandingkan dengan prevalensi Diabetes di Amerika Serikat (8,3\%) dan Cina (3,9\%), maka Indonesia sebagai negara berkembang berada diantaranya (Suyono, 2009). Sedangkan, prevalensi Diabetes di provinsi Lampung $6,2 \%$ berada di atas angka nasional (5,7\%). Prevalensi Diabetes di provinsi Lampung dari $10 \mathrm{kabupaten/kota}$ berdasarkan diagnosis tenaga kesehatan tertinggi di kota Metro berjumlah 0,7\% dan hasil Riskesdas 2013 di provinsi Lampung turun menjadi 0,7\% (Badan Litbangkes Kemenkes RI, 2013).

Diabetes tipe 2 merupakan gangguan yang dipengaruhi oleh multifaktor, melibatkan baik faktor genetik maupun faktor lingkungan sosial (Fain, 2014). Diabetes tipe 2 adalah tipe Diabetes paling umum, mengenai $90 \%$ orang dari semua penderita Diabetes dan tidak berhubungan dengan tipe jaringan human leukocyte antigens (HLAs) dan sel antibodi islet (ICAs) jarang ada. Faktor keturunan memainkan peran utama didalam ekspresi dari Diabetes tipe 2. Diabetes tipe 2 lebih umum terjadi pada kembar identik (5875\%) dibandingkan populasi umum (Fain, 2014). Penelitian sebelumnya yang memperkuat dilakukan di kota Depok oleh (Rahmawati, Setiarini, \& Sudikno, 2009) memperoleh 63,6\% pasien Diabetes tipe 2 dengan riwayat Diabetes tipe 2 dalam keluarga. Angka ini lebih besar daripada pasien Diabetes tipe 2 yang tidak memiliki riwayat Diabetes tipe 2 dalam keluarga $(16,8 \%)$ dan faktor keturunan sebagai faktor yang dominan terjadinya Diabetes (OR =6,628; 95\% CI: 2,061-21,317). Namun, faktor keturunan untuk sampai terkena efek Diabetes ada beberapa faktor yang melatarbelakangi, seperti infeksi virus, kegemukan, pola makan yang salah, minum obat-obatan yang bisa menaikkan kadar glukosa dalam darah, proses menua, stres, dan faktor lainnya (Suyono, 2009). Obesitas menjadi faktor risiko mayor (85\%) dari seluruh orang dengan Diabetes tipe 2 dan juga penelitian oleh (Irawan, 2010) memperlihatkan bahwa obesitas merupakan faktor risiko yang dominan terjadinya Diabetes tipe 2. 
Obesitas yang menjadi faktor peningkatan penyandang Diabetes tipe 2, karena perubahan gaya hidup, seperti aktivitas fisik kurang, merokok, diet tidak sehat dan penggunaan alkohol (Narayan, 2011) (Suyono, S, 2009). Secara nasional terdapat sejumlah 18,8\% responden dengan obesitas dan kurang aktivitas fisik pada kelompok umur $>10$ tahun terdapat 48,2\%. Prevalensi Diabetes pada orang obesitas (IMT $\geq 27$ ) berjumlah 9,1\% dan obesitas sentral 9,7\% (Badan Litbangkes Depkes RI, 2008). Faktor resiko lain yang mempengaruhinya terjadinya Diabetes adalah faktor lingkungan dan sosiodemografi, antara lain umur, jenis kelamin, tingkat pendidikan dan pekerjaan.

Berbagai penelitian dan referensi tersebut tentang terjadinya Diabetes Tipe 2 merupakan penyakit multifaktorial dengan komponen genetik dan lingkungan yang diduga sama-sama memberi pengaruh sama kuat karena ada interaksi. Selain itu, masih jarang penelitian dengan analisis multivariat dengan model estimasi menjadikan faktor keturunan sebagai variabel independen utama untuk menemukan besar estimasi. Oleh karena itu, penelitian ini dengan analisis multivariat model studi estimasi bertujuan memperoleh besar estimasi faktor risiko keturunan terhadap kejadian tipe 2 dengan mengkontrol mengontrol variabel perancu meliputi umur, jenis kelamin, riwayat keturunan Diabetes mellitus, pendidikan, pekerjaan, merokok, aktivitas olah raga, hipertensi dan memperoleh attributable fraction persen (AF\%).

\section{Metode}

Penelitian ini menggunakan desain cross sectional dengan model estimasi, dipilih sebagai vairiabel utama adalah faktor keturunan. Rancangan penelitian dipilih untuk menganalisis estimasi keturunan terhadap kejadian Diabetes tipe 2 dengan variabel kovariat meliputi umur, jenis kelamin, pendidikan, pekerjaan, status merokok, IMT, aktivitas olah raga, hipertensi dan obesitas central yang dilaksanakan sampai selesai bulan Februari 2016. Populasi penelitian adalah semua pasien di rawat jalan Poliklinik dan bangsal penyakit dalam RSUD Ahmad Yani Metro provinsi Lampung. Sampel penelitian berjumlah 249 responden yang dihitung menggunakan rumus uji hipotesis beda dua proporsi dengan derajat kemaknaan $\left(\mathrm{Z}_{1}-\alpha / 2\right) 95 \%(1,96)$ dan tingkat kekuatan uji $\left(\mathrm{Z}_{1-\beta}\right) 90 \%$. Sampel dikumpulkan dengan teknik consecutive sampling sesuai kriteria inklusi dan eksklusi penelitian.

Pengukuran dan pengamatan variabel penelitian menggunakan metode: (1) wawancara menggunakan kuesioner, untuk mengumpulkan data variabel riwayat keturunan Diabetes, aktifitas olah raga, status merokok, pendidikan, pekerjaan, umur, dan jenis kelamin; (2) pengamatan dan pemeriksaan untuk mengumpulkan data kejadian Diabetes tipe 2, obesitas sentral, Indeks Massa Tubuh (IMT), dan hipertensi. Pengumpulan data mempertimbangkan informed consent sebagai implementasi pertimbangan etika penelitian yang dilakukan. Instrumen pengumpulan data dikonstruksi dengan memodifikasi kuesioner skrining deteksi dini pengendalian penyakit tidak menular oleh Kemenkes RI tahun 2011.

Data yang telah dikumpulkan dianalisis bertahap mulai analisis univariat, bivariat dan multivariate dengan model estimasi menggunakan uji multiple regresi logistic. Besar asosiasi memenuhi syarat kemaknaan, jika prevalensi odd rasio $(\mathrm{POR})>1$ dan nilai $\mathrm{p}<0,05$. Data juga dianalisis menggunakan perhitungan attributable fraction persen $(\mathrm{AF} \%)$ untuk melihat efek pada outcome, jika dilakukan upaya preventif terhadap eksposure.

\section{Hasil}

\section{Karakteristik responden}

Hasil analisis menunjukkan gambaran responden dari variabel kovariat menunjukkan bahwa sebagian besar responden (70,7\% orang) berusia $\geq 45$ tahun, dan berjenis kelamin perempuan $(56,6 \%)$ dan tidak bekerja (53\%), berpendidikan tinggi atau SMA dan PT (55,8\%) dari 249 responden. Selain itu, terdapat 
23,3 mengalami overweight dan (IMT $\left.\geq 27 \mathrm{~kg} / \mathrm{cm}^{2}\right)$, kurang dalam beraktivitas olahraga $(<3 \mathrm{x} / \mathrm{minggu}$ selama 30 menit) sejumlah 75,9\%, dominan tidak hipertensi $(79,9 \%)$ dan tidak merokok atau merokok $<20$ batang/hari ada $96,4 \%$ dari 249 .

\section{Analisis bivariat untuk seleksi kandidat variabel multivariat}

Tabel 1 menunjukkan hasil analisis seleksi kandidat multivariat, jika dari hasil uji statistik mempunyai nilai $\mathrm{p}<0,25$ maka variabel tersebut memenuhi sayat masuk model awal multivariat.

Tabel 1.

Hasil analisis bivariat seleksi untuk kandidat model multivariat

\begin{tabular}{|c|c|c|c|}
\hline Variabel & Kategori & $P$ value & POR 95\% CI \\
\hline Obesitas sentral & Lingkar abdomen $(\mathrm{P}:>80 \mathrm{~cm}$ dan $\mathrm{L}:>90 \mathrm{~cm}$ & $0,001 *$ & $2,749(1,547-4,883)$ \\
\hline Keturunan & $\mathrm{Ya}$ & $0,000^{*}$ & $9,043(4,617-17,714)$ \\
\hline Umur & $\geq 45$ tahun & $0,003 *$ & $3,097(1,481-6,474)$ \\
\hline Jenis kelamin & Perempuan & 1,000 & $1,042(0,593-1,829)$ \\
\hline Bekerja & Tidak bekerja & 0,485 & $1,273(0,725-2,232)$ \\
\hline Pendidikan & SMP ke bawah & 1,000 & $0,997(0,569-1,747)$ \\
\hline Aktivitas olah raga & Kurang & $0,196^{*}$ & $1,684(0,832-3,410)$ \\
\hline Hipertensi & Ya & $0,015^{*}$ & $2,342(1,223-4,486)$ \\
\hline Merokok & $\geq 20 \mathrm{btg} / \mathrm{hari}$ & $0,066^{*}$ & $3,512(0,914-13,491)$ \\
\hline
\end{tabular}

*nilai $\mathrm{p}<0,25$ masuk kandidat multivariat

\section{Model awal multivariat}

Tabel 2 menunjukkan variabel kovariat yang yang memenuhi syarat masuk kandidat awal multivariat karena mempunyai nilai $\mathrm{p}<0,25$. Variabel tersebut adalah obesitas sentral, faktor keturunan, umur, status merokok, IMT, aktivitas olah raga, sedangkan hipertensi dimasukkan ke dalam model multivariat karena pertimbangan secara substansi dianggap penting.

Tabel 2.

Model awal multivariat pengaruh keturunan terhadap kejadian Diabetes tipe 2 dengan variabel kovariat lain

\begin{tabular}{lcccccc}
\hline \multicolumn{1}{c}{ Variabel } & B & S.E. & P value & Exp(B) & \multicolumn{2}{c}{ 95.0\% C.I. } \\
\cline { 5 - 7 } & & & & & Lower & Upper \\
\hline Obesitas sentral & 1.412 & 0.420 & 0.001 & 4.105 & 1.803 & 9.343 \\
Faktor keturunan & 2.659 & 0.417 & 0.000 & 14.282 & 6.302 & 32.368 \\
Umur & 0.768 & 0.435 & 0.077 & 2.155 & 0.919 & 5.049 \\
Pekerjaan & 0.650 & 0.369 & 0.078 & 1.915 & 0.930 & 3.945 \\
IMT & -0.891 & 0.473 & 0.060 & 0.410 & 0.162 & 1.037 \\
Hipertensi & 0.401 & 0.400 & 0.317 & 1.493 & 0.681 & 3.272 \\
Aktivitas olah raga & 0.713 & 0.445 & 0.110 & 2.039 & 0.852 & 4.882 \\
Merokok & 1.525 & 0.830 & 0.066 & 4.596 & 0.903 & 23.392 \\
& -3.345 & 0.978 & 0.001 & 0.035 & & \\
\hline
\end{tabular}

\section{Pembuatan model lengkap multivariat}

Model lengkap multivariat mencakup variabel utama, variabel kandidat counfounding (perancu) yang mempunyai nilai $\mathrm{p}<0,25$ dan variabel interaksi (interaksi antara variabel utama dan variabel kovariat). Analisis pemodelan multivariat dilakukan dengan memasukkan secara bersama-sama, sehingga diperoleh hasil yang disajikan pada tabel 3 . 
Faktor Risiko Keturunan dengan Variabel Perancu Meningkatkan Risiko Prevalensi Diabetes Tipe 2 ... Riyanto Riyanto

Jurnal Kesehatan Metro Sai Wawai. 10 (2) 2017. E-ISSN2657-1390. P-ISSN19779-469X

Tabel 3.

Model lengkap multivariat pengaruh obesitas sentral terhadap kejadian Diabetes tipe 2 dengan variabel kovariat lain

\begin{tabular}{lcccccc}
\hline \multicolumn{1}{c}{ Variabel } & \multirow{2}{*}{$\mathbf{B}$} & S.E. & P value. & Exp(B) & \multicolumn{2}{c}{$\mathbf{9 5 . 0 \%} \mathbf{C}$} \\
\cline { 5 - 8 } & & & & Lower & Upper \\
\hline Riwayat keturunan & 2.214 & .653 & .001 & 9.156 & 2.545 & 32.935 \\
Obesitas sentral & .163 & .778 & .834 & 1.177 & .256 & 5.407 \\
Umur & 2.474 & .930 & .008 & 11.865 & 1.917 & 73.424 \\
Pekerjaan & .596 & .379 & .116 & 1.815 & .863 & 3.816 \\
IMT & -.578 & .472 & .221 & .561 & .223 & 1.415 \\
Hipertensi & .482 & .416 & .247 & 1.619 & .716 & 3.661 \\
Aktivitas olah raga & .503 & .769 & .513 & 1.654 & .366 & 7.471 \\
Merokok & 1.179 & .828 & .155 & 3.252 & .641 & 16.493 \\
Obesitas sentral dengan faktor keturunan & 1.543 & .843 & .067 & 4.679 & .896 & 24.428 \\
Faktor keturunan dengan umur & -2.323 & 1.057 & .028 & .098 & .012 & .777 \\
Aktivitas dengan faktor keturunan & .302 & .974 & .756 & 1.353 & .201 & 9.124 \\
\multicolumn{1}{c}{ Constant } & -2.824 & 1.073 & .008 & .059 & & \\
\hline
\end{tabular}

\section{Pengujian variabel interaksi pemodelan multivariat}

Langkah selanjutnya melakukan uji interaksi. Uji Interaksi dilakukan dengan mengeluarkan variabel kandidat interaksi satu persatu dari model dimulai dari variabel yang memiliki nilai p terbesar, yaitu interaksi antara faktor keturunan*aktivitas $(\mathrm{p}=0,756)$ dan seterusnya, jika diperoleh nilai $\mathrm{p}<0,05$ berarti terdapat interaksi dan dipertahankan dalam model multivariat. Hasil uji interaksi diperoleh hasil terdapat interaksi antara variabel riwayat keturunan*umur memperlihatkan nilai p $0.043(<0,05)$ artinya bahwa hubungan riwayat keturunan dengan kejadian Diabetes tipe 2 memberikan efek yang berbeda (bersamasama), bila responden berumur $\geq 45$ tahun, sehingga dipertahankan dari model (lihat tabel 4).

\section{Pengujian variabel confounding pemodelan multivariat}

Confounder atau faktor perancu merupakan variabel independen lain yang perlu dikendalikan dalam penelitian ini, karena diduga dapat memberikan efek distorsi dalam menaksir kualitas hubungan riwayat keturunan terhadap kejadian Diabetes tipe 2. Penilaian confounding pada analisis multivariat dilakukan terhadap variabel kovariat yang terpilih masuk sebagai model, yaitu obesitas sentral, umur, pekerjaan, IMT, hipertensi, aktivitas olah raga, dan merokok.

Tabel 4.

Hasil analisis pengujian variabel obesitas sentral sebagai confounder dari model gold standart hubungan faktor keturunan dengan kejadian Diabetes tipe 2

\begin{tabular}{lcccccc}
\hline \multicolumn{1}{c}{ Variabel } & \multirow{2}{*}{ B } & S.E. & P value & Exp(B) & \multicolumn{2}{c}{ 95.0\% C.I. } \\
\cline { 6 - 7 } & & & & & Lower & Upper \\
\hline Riwayat keturunan & 2.986 & .466 & .000 & 19.810 & 7.948 & 49.376 \\
Riwayat keturunan by umur & -1.988 & .988 & .044 & .137 & .020 & .950 \\
IMT & -.700 & .467 & .134 & .497 & .199 & 1.240 \\
Pekerjaan & .664 & .365 & .069 & 1.942 & .949 & 3.974 \\
Umur & 2.231 & .878 & .011 & 9.308 & 1.666 & 51.985 \\
Obesitas sentral & 1.416 & .413 & .001 & 4.122 & 1.834 & 9.263 \\
\multicolumn{1}{c}{ Constant } & -1.818 & .503 & .000 & .162 & & \\
\hline \multicolumn{2}{c}{} \\
\cline { 1 - 4 }
\end{tabular}


Penilaian confounder dengan cara melihat perbedaan POR pada analisis multivariat menggunakan uji regresi logistik ganda dan membandingkan nilai POR, apabila $\geq 10 \%$, maka variabel tersebut dapat dinyatakan sebagai confounder, dan dipertahankan tetap dalam model. Rumus menghitung perubahan atau perbedaan POR adalah:

$$
\text { Perbedaan POR }=\frac{\text { PORcrude }-- \text { PORadjust }}{\text { PORadjustt }} \times 100 \%
$$

Hasil perhitungan diperoleh perubahan nilai POR $\geq 10 \%$ adalah IMT (14\%), pekerjaan (16\%), umur (33\%) dan obesitas sentral (24\%), artinya sebagai variabel perancu (confounder), sehingga dipertahankan dalam model multivariat. Sedangkan, variabel hipertensi (1\%), aktivitas olah raga (7\%) dan merokok $(0,4 \%)$ bukan sebagai confounder karena mempunyai perubahan nilai POR $<10 \%$, sehingga dikeluarkan dari model multivariat.

\section{Model akhir multivariat kejadian Diabetes tipe 2}

Hasil analisis pemodelan multivariat akhir menunjukkan faktor keturunan berhubungan dengan kejadian Diabetes tipe 2 (p value 0,000), setelah dikontrol oleh faktor perancu (confounding) IMT, pekerjaan, umur dan obesitas sentral. Artinya variabel IMT, pekerjaan, umur dan obesitas sentral menjadi perancu keturunan sebagai faktor risiko seseorang menderita Diabetes tipe 2. Estimasi faktor keturunan berisiko 19.8 kali dapat mengalami Diabetes dibandingkan yang tidak mempunyai faktor keturunan (PORadjusted 19,8; 95\% CI: 1,911-9,459) setelah dikontrol faktor resiko lainnya, yaitu IMT, pekerjaan dan umur dan obesitas sentral. Perhitungan ukuran dampak potensial (AF\%) hasil analisis memperoleh sebesar $48,15 \%$. Artinya berjumlah sekitar $48 \%$ seseorang yang menderita diabetes tipe 2 dengan faktor keturunan Diabetes dapat dicegah, jika seseorang mengeliminasi faktor risiko atau atau melakukan intervensi terhadap berbagai faktor risiko faktor keturunan Diabetes.

Tabel 5.

Model Akhir Multivariat Hubungan Riwayat Keturunan dengan Kejadian Diabetes Tipe 2 Setelah dikontrol confounding

\begin{tabular}{|c|c|c|c|c|c|c|}
\hline \multirow{2}{*}{ Variabel } & \multirow{2}{*}{ B } & \multirow{2}{*}{ S.E. } & \multirow{2}{*}{$\mathrm{P}$ value } & \multirow{2}{*}{$\operatorname{Exp}(B)$} & \multicolumn{2}{|c|}{ 95.0\% C.I. } \\
\hline & & & & & Lower & Upper \\
\hline Riwayat keturunan & 2.986 & .466 & .000 & 19.810 & 7.948 & 49.376 \\
\hline Riwayat keturunan by umur & -1.988 & .988 & .044 & .137 & .020 & .950 \\
\hline IMT & -.700 & .467 & .134 & .497 & .199 & 1.240 \\
\hline Pekerjaan & .664 & .365 & .069 & 1.942 & .949 & 3.974 \\
\hline Umur & 2.231 & .878 & .011 & 9.308 & 1.666 & 51.985 \\
\hline Obesitas sentral & 1.416 & .413 & .001 & 4.122 & 1.834 & 9.263 \\
\hline Constant & -1.818 & .503 & .000 & .162 & & \\
\hline
\end{tabular}

\section{Pembahasan}

\section{Prevalensi Diabetes melitus tipe 2}

Diabetes merupakan penyakit kronis yang ditandai dengan peningkatan kadar glukosa dalam darah (hiperglikemia) lebih dari $200 \mathrm{mg} / \mathrm{dL}$ (Fain, 2014). Prevalensi Diabetes tipe 2 hasil penelitian yang dilakukan kunjungan di poli klinik penyakit dalam RSUD Jendral Ahmad Yani kota Metro berjumlah 27,3 $\%$ dari 249 responden. Hasil penelitian ini lebih tinggi dari penelitian di Puskesmas Bahu kota Manado pada Januari 2015 yang oleh menunjukkan bahwa responden memiliki rerata kadar glukosa darah meningkat (> 
$200 \mathrm{mg} / \mathrm{dl}$ ) sejumlah 18,2\% (Suci , Herlina , \& Damajanty, 2015) dan penelitin oleh (Syaini, 2013) di Johor Baru Jakarta Pusat dari data skring penyakit tidak menular tahun 2012 diperoleh prevalensi Diabetes tipe 2 dengan faktor keturunan keluarga sejumlah 24,2\% dari 265 responden. Namun, lebih rendah dari penelitian di kota Depok oleh (Rahmawati, Setiarini, \& Sudikno, 2009) mememperoleh 63,6\% pasien Diabetes tipe 2 dengan riwayat Diabetes tipe 2 dalam keluarga. Sedangkan, penyakit Diabetes tipe 2 sekitar $90 \%$ dari total kasus DM global (Perkeni, 2015).

Perhitungan ukuran dampak potensial (AF\%) hasil analisis memperoleh sebesar 48,15\%. Artinya berjumlah sekitar $48 \%$ seseorang yang menderita diabetes tipe 2 dengan faktor keturunan Diabetes dapat dicegah, jika seseorang mengeliminasi faktor risiko atau atau melakukan intervensi terhadap berbagai faktor risiko faktor keturunan Diabetes. Oleh karena itu, perlu upaya pencegahan dan pengendalian, karena sebagain orang ada yang tidak mengetahui bahwa dirinya menderita Diabetes dan akan mengalami peningkatan risiko terhadap komplikasi kronis Diabetes, seperti gangguan pada mata dan katarak (retinopati), gangguan fungsi ginjal (nefropati), gangguan syaraf (neuropati), ulkus pada kaki dan amputasi, infeksi, penyakit jantung, stroke karena tidak mendapatkan pengobatan yang adekuat, beban ekonomi dan beban seumur hidup, karena penyembuhan sulit total.

\section{Estimasi faktor risiko keturunan dan kejadian Diabetes tipe 2}

Diabetes tipe 2 dikenal sebagai diabetes life style, karena yang menjadi penyebab adalah faktor keturunan dan faktor lingkungan, meliputi usia, obesitas, resistensi insulin, makanan, aktifitas fisik, selain itu gaya hidup tidak sehat sangat berperan sebagai faktor risiko seseorang menderita penyakit diabetes ini. Hasil analisis bivariat memperlihatkan hubungan faktor keturunan terhadap kejadian diabetes tipe 2 dengan risiko sebesar 14,2 kali dibandingkan yang tidak mempunyai faktor keturunan ( $\mathrm{POR}=14,282$; $95 \% \mathrm{CI}$ : 6,302-32,368). Sedangkan, hasil analisis pemodelan multivariat akhir dengan model studi estimasi untuk mencari faktor perancu menemukan bahwa faktor keturunan berhubunganan dengan kejadian Diabetes tipe 2 ( $\mathrm{p}$ value 0,000 ), setelah dikontrol oleh faktor perancu (confounding) IMT, pekerjaan, umur dan obesitas sentral dengan besar estimasi diperoleh ORadjusted 19,8 dengan 95\% CI: 7,948-49,376). Artinya estimasi responden yang mempunyai faktor keturunan berisiko 19.8 kali dapat mengalami Diabetes dibandingkan yang tidak mempunyai faktor keturunan (ORadjusted 19,8; 95\% CI: 1,911-9,459) setelah dikontrol perancu IMT, pekerjaan dan umur dan obesitas sentral.

Hasil penelitian memperoleh besar faktor risiko (odds rasio) keturunan terhadap kejadian Diabetes tipe 2 yang lebih besar jika dibandingkan dengan penelitin sebelumnya. Perbedaan tersebut lebih disebabkan karena perbedaan desain penelitian dengan analisis model estimasi (pada penelitian ini). Penelitian dengan rancangan studi kasus kontrol oleh (Kekenusa, Ratag, \& Wuwungan, 2013) pada pasien rawat jalan di Poliklinik Penyakit Dalam BLU RSUP Prof. Dr. RD Kandou Manado orang yang memiliki riwayat keluarga menderita DM 5 kali lebih berisiko menderita DM Tipe 2 dibandingkan dengan orang yang tidak memiliki riwayat keluarga menderita $\mathrm{DM}$ dengan nilai $\mathrm{p}=0,000(\mathrm{OR}=4,7 ; 4,707(2,702-8,199)$.

Diabetes tipe 2 merupakan gangguan yang dipengaruhi oleh multifaktor, melibatkan baik faktor genetik maupun faktor lingkungan sosial (Fain, 2014). Namun, untuk sampai terkena efek DM ada beberapa faktor yang melatarbelakangi, seperti infeksi virus, kegemukan, pola makan yang salah, minum obat-obatan yang bisa menaikkan kadar glukosa dalam darah, proses menua, stres, dan lain-lain (Suyono, 2009). Pernyataan ini didukung oleh penelitian oleh (Rahmawati, Setiarini, \& Sudikno, 2009) terhadap seluruh Pegawai Negeri Sipil (PNS) di lingkungan Pemda Kota Depok tahun 2009 dengan rancangan kasus kontrol dan analisis multivariat memperoleh besar faktor risiko yang paling tinggi (dominan) adalah riwayat diabetes, yaitu 6,6 kali untuk mengalami hiperglikemia (ORadjusted 6,628; 95\% CI: 2,061 -21,317), setelah 
dikontrol dengan status gizi dan konsumsi protein. (Suyono, 2009) menjelaskan bila orang tua menderita DM maka anaknya akan berisiko untuk menderita juga. Jika ada anggota keluarga yang DM, maka seseorang akan berpeluang mendapatkan DM dua kali lebih tinggi dibandingkan orang yang tidak mempunyai keluarga dengan DM. risiko anak lebih besar ketika orang tuanya yang menderita diabetes tipe 2 adalah ibu, tapi resiko akan meningkat satu banding dua jika kedua orang tuanya menderita DM tipe 2 .

Berbagai klasifikasi Diabetes yang paling umum adalah Diabetes tipe 2, mengenai sekitar 90\% orang dari semua penderita Diabetes dan tidak berhubungan dengan tipe jaringan human leukocyte antigens (HLAs) dan sel antibodi islet (ICAs) jarang ada seperti pada Diabetes tipe 1. Faktor keturunan memainkan peran utama didalam ekspresi dari Diabetes tipe 2. Defek genetik pada sel beta dapat mengarah perkembangan Diabetes dan resistensi insulin (Fain, 2014).

Patogenesis Diabetes tipe 2 sesuai pernyataan (Fain, 2014) bahwa respon terbatas sel beta terhadap hiperglikemia tampak menjadi faktor mayor dalam perkembangannya. Sel beta yang terpapar secara kronis terhadap kadar glukosa darah tinggi menjadi secara progresif kurang efisien ketika merespons penngkatan glukosa lebih lanjut. Selain itu, resistensi insulin baik di hati maupun di perifer pada orang dengan Diabetes tipe 2 memiliki penurunan sensitivitas insulin terhadap kadar glukosa, yang mengakibatkan produksi hepatik berlanjut, bahkan sampai dengan kadar glukosa darah tinggi. Hal ini bersamaan dengan ketidakmampuan otot dan jaringan lemak untuk meningkatkan ambilan glukosa. Mekanisme penyebab resistensi insulin perifer belum jelas, namun ini tampak terjadi setelah insulin berikatan berikatan terhadap reseptor pada permukaan sel.

Faktor risiko lain Diabetes adalah life style yang tidak sehat yang mengakibatkan obesitas, bertambahnya usia. Hasil analisis penelitian menemukan bahwa faktor keturunan berhubunganan dengan kejadian Diabetes tipe 2, setelah dikontrol oleh faktor perancu (confounding) IMT, pekerjaan, umur dan obesitas sentral. Berbagai hasil penelitian menemukan bahwa obesitas menjadi faktor risiko tertinggi yang menyebabkan terjadinya Diabetes tipe 2. Menurut (Fain, 2014) bahwa obesitas adalah risiko mayor (85\%) dari penyandang Diabetes tipe 2. Hal ini tidak jelas apakah terjadi sensitivitas jaringan (otot dan hati) terhadap insulin atau kegagalan sekresi insulin merupakan efek primer Diabetes tipe 2.

Umur juga merupakan faktor yang sangat penting dalam pengaruhnya terhadap prevalensi diabetes bersama-sama dengan faktor riwayat keturunan. Dalam studi epidemiologi, baik yang dilakukan secara cross sectional maupun lungitudional, menunjukkan bahwa prevalensi diabetes naik bersama bertambahnya umur. WHO menyebutkan bahwa setelah seseorang mencapai umur 30 tahun maka kadar glukosa darah akan naik 1-2 mg/dl per tahun pada saat puasa dan akan naik sekitar 5,6-13\% pada 2 jam setelah makan. Usia muda dalam (Luciana, 2008) merupakan kelompok usia yang berisiko rendah (protektif) dan risiko akan meningkat sejalan dengan meningkatnya umur. DM tipe 2 biasanya terjadi setelah usia 30 tahun dan semakin sering terjadi setelah usia 40 tahun, selanjutnya terus meningkat pada usia lanjut. Usia lanjut yang mengalami gangguan toleransi glukosa mencapai 50-92\%. Sekitar 6\% individu berusia 45-64 tahun dan 11\% individu diatas usia 65 tahun menderita DM tipe 2 (Rachmah, 2006).

Perhitungan ukuran dampak potensial (AF\%) hasil analisis memperoleh sebesar 48,15\%. Artinya berjumlah sekitar $48 \%$ seseorang yang menderita diabetes tipe 2 dengan faktor keturunan Diabetes dapat dicegah, jika seseorang mengeliminasi faktor risiko atau atau melakukan intervensi terhadap berbagai faktor risiko faktor keturunan Diabetes. Untuk itu, upaya penurunan dan pengendaliaan Diabetes tipe 2 sangat urgen untuk dilakukan terkait pengandang yang memiliki fakktor keturunan Diabetes, hendaknya menjalani gaya hidup yang sehat. Gaya hidup sehat dengan menjaga berat badan normal sejak kecil dengan menjaga pola makan seimbang, mengurangi makanan olahan tinggi gula dan lemak jenuh dan olah raga teratur. 
Selain itu, saat penyandang Diabetes sudah berusia > 30 tahun, hendaknya melakukan skrining secara teratur setiap tahun untuk deteksi dini atau melakukan pemeriksaan gula darah segera bila ada tanda-tanda hiperklikemia berguna untuk melakukan tindakan dini dan pencegahan komplikasi kompleks.

\section{Simpulan dan saran}

Hasil penelitian menyimpulkan dari analisis pemodelan multivariat akhir menemukan bahwa faktor keturunan berhubunganan dengan kejadian Diabetes tipe 2, setelah dikontrol oleh faktor perancu (confounding) IMT, pekerjaan, umur dan obesitas sentral dengan besar estimasi responden yang mempunyai faktor keturunan berisiko 19.8 kali dapat mengalami Diabetes dibandingkan yang tidak mempunyai faktor keturunan setelah dikontrol perancu IMT, pekerjaan dan umur dan obesitas sentral. Perhitungan ukuran dampak potensial (AF\%) hasil analisis memperoleh sebesar 48,15\%. Hendaknya pengandang Diabetes tipe 2 yang mempunyai riwayat keturunan Diabetes, menjalani gaya hidup yang sehat. Gaya hidup sehat dengan menjaga berat badan normal sejak kecil dengan menjaga pola makan seimbang, mengurangi makanan olahan tinggi gula dan lemak jenuh dan olah raga teratur. Selain itu, saat penyandang Diabetes sudah berusia $>30$ tahun, hendaknya melakukan skrining secara teratur setiap tahun untuk deteksi dini atau melakukan pemeriksaan gula darah segera bila ada tanda-tanda hiperklikemia berguna untuk melakukan tindakan dini dan pencegahan komplikasi kompleks.

\section{Referensi}

Badan Litbangkes Depkes RI. (2008). Riset Kesehatan Dasar Tahun 2007. Jakarta: Depkes RI.

Badan Litbangkes Kemenkes RI. (2013). Riset Kesehatan Dasar Tahun 2013. Jakarta: Badan Litbangkes Kemenkes RI.

Biswah, A. (2006). Prevention of type 2 Diabetes-life style modification with diet and psysical activity vs psysicala activity. Korolinska Institutes.

Fain, J. A. (2014). Penatalaksanaan pada klien dengan Diabetes melitus In Keperawatan medikal bedah: manajemen klinis untuk hasil yang diharapkan. $8 \mathrm{Ed}$. Vol 2. Singapura: Elseiver.

IDF. (2015). International Diabetes Federation. 2015. IDF Diabetes Atlas 7th Edition. Brussels: International Diabetes Federation . Retrieved from http://www. diabetes atlas. org/. form 9 Februari 2014.

Irawan, D. (2010). prevalensi dan faktor resiko kejadian Diabetes tipe 2 di daerah urban Indonesia. Thesis. FKM Universitas Indonesia. Thesis. Depok: Analisis Data Sekunder Riskesdas 2007.

Kekenusa, J. S., Ratag, B. T., \& Wuwungan, G. (2013). Analisis hubungan antara umur dan riwayat keluarga menderita Diabetes dengan kejadian penyakit Diabetes tipe 2 pada pasien rawat jalandi poliklinik penyakit dalam BL DR. R.D Kandau Manado. Manado: FKM Universitas Sam Ratulangi Manado. Retrieved Mei 8, 2013, from http://fkm.unsrat.ac.id

Kemenkes RI. (2014). Profil kesehatan Indonesia tahun 2014. Jakarta: Kemenkes RI.

Luciana, E. (2008). Hubungan aktivitas fisik dengan kendali gula darah pada penyandang diabetes tipe 2 di RS Husada Jakarta. Thesis. Depok: FKM Universitas Indonesia.

Narayan, E. A. (2011). Diabetes public health pinted. Oxford University Press. United States of America: on acid-free Paper.

Perkeni. (2015). Konsesus pengelolaan dan pencegahan diabetes melitus tipe 2 di Indonesia tahun 2015. Tanpa Kota: PB Perkeni.

Rachmah, W. (2006). Diabetes meliitus pada usia lanjut dalam buku ajar ilmu penyakit dalam.Volume III (3 ed.). Jakarta: Fakultas Kedokteran Universitas Indonesia. 
Faktor Risiko Keturunan Diabetes dengan Variabel Perancu Meningkatkan Risiko Prevalensi Diabetes Tipe 2 ... Riyanto Riyanto

Jurnal Kesehatan Metro Sai Wawai. 10 (2) 2017. E-ISSN2657-1390. P-ISSN19779-469X

Rahmawati, Setiarini, A., \& Sudikno. (2009). Pengaruh status gizi terhadap kejadian hiperglikemia pada pegawai negeri sipil: studi kasus kota depok tahun 2009. Jurnal Gizi Indonesia. 32(1): 63-65.

Syaini, R. I. (2013). Hubungan obesitas sentral terhadap kejadian DM tipe 2 di kelurahan Johor Baru Jakarta Pusat Tahun 2012. Thesis. FKM UI, Depok.

Suci, M. A., Herlina, W., \& Damajanty, P. (2015). Kadar glukosa darah sewaktu pada pasien diabetes melitus tipe 2 di Puskesmas Bahu kota Manado. Jurnal e-Biomedik (eBm), 3(1): 32-40 .

Suyono, S. (2009). Kecenderungan peningkatan jumlah penyandang Diabetes dalam penatalaksanaan diabetes terpadu. Vol 2 (7 ed.). Jakarta: Balai Penerbit Fakultas Kedokteran Universitas Indonesia.

Suyono, S. (2009). Patofifiologi Diabetes mellitus dalam penatalaksanaan DIABETES terpadu. Volume 2 (7 ed.). Jakarta: Balai Penerbit Fakultas Kedokteran Universitas Indonesia. 